\title{
Metinsel edimler doğrultusunda Türkçe bilimsel metinlerde kullanılan olumsuz tümcelerin görünümü ${ }^{1}$
}

\section{Sevgi ÇALIŞIR ZENCİ²}

\begin{abstract}
APA: Çalışır Zenci, S. (2020). Metinsel edimler doğrultusunda Türkçe bilimsel metinlerde kullanılan olumsuz tümcelerin görünümü. RumeliDE Dil ve Edebiyat Araştırmaları Dergisi, (20), 190-201. DOI: $10.29000 /$ rumelide.791135.
\end{abstract}

\section{$\ddot{O} \mathbf{z}$}

Son yıllarda dilbilimde olumsuzluk konusu üzerine pek çok çalışma yapılmıştır. Bugüne kadar yapılan olumsuzluk çalışmalarında, olumsuzluğun daha çok sözdizimsel ve anlamsal boyutu üzerine yoğunlaşılmıştır. Metinsel düzlemde işaretlenen olumsuzluğa ise yeterince değinilmemiştir. Bu çalışmanın amacı, dilbilim alanında Türkçe yazılmış bilimsel metinlerde kullanılan olumsuzluğun metinsel edimlere göre dağılımlarını incelemektir. Çalışmada, doküman inceleme yöntemi kullanılmıştır. Çalışmanın veri tabanı, dilbilim alanında Türk yazarlar tarafından yazılmış Türkçe bilimsel metinlerden oluşmaktadır. Çalışmada incelenen örneklem, 1998-2006 yıllarında yayımlanan Dilbilim Araştırmaları ve Dilbilim Kurultay Bildirileri’nden rastlantısal örnekleme yöntemiyle 20 bilimsel metin seçilmiştir. İncelemede sayısal değerler iki aşamalı bir sayım yapılarak saptanmıştır. Sayımın birinci aşamasında dilbilim alanında Türkçe yazılmış bilimsel metinlerdeki toplam sözce sayısı (2845) saptanmıştır. Bunun ardından ikinci olarak dilbilim alanında Türkçe yazılmış bilimsel metinlerde yer almakta olan olumsuz sözcelerin (210) sayısı saptanmıştır. Saptanan olumsuz sözceler Swales (1990)'in metinsel edim modeline göre düzenlenmiştir. Türkçe bilimsel metinlerde kullanılan olumsuz tümcelerin, en sık kullanıldığı metinsel edimler sırasıyla; Konu ile İlgili Genellemeler (80), Çıkarım ve Varsayım (52), Araştırma Eksikliği Belirtme (22), Beklenmeyen Sonuç (22), Alan Yazın Değerlendirmesi (14), Sorun Belirtme (9), Açıllama (4), Öneri (2), Sınırlılıklar (2), Yöntem (2), Veri Toplama İşlemleri (1)'dir. Çalışmada bilimsel metinlerde kullanılan olumsuz tümcelerin, çalışmanın inandırıcılığını, güvenirliğini, yeterliliğini gibi durumları etkilediği sonucuna varılmıştır.

Anahtar kelimeler: Türkçe bilimsel metinler, metinsel edimler, olumsuz tümceler

\section{The appearance of negative sentences used in Turkish scientific texts in line with textual acts}

\begin{abstract}
In recent years, many studies have been examined on the issue of negation in linguistics. In the negation studies carried out to date, the syntax and semantic dimension of negation is mostly focused on. The negation marked in the textual context has not been sufficiently addressed. The purpose of this study is to examine the distribution of negation used in scientific texts in Turkish in the field of linguistics according to textual acts. In the study, document review method was used. The database of the study consists of Turkish scientific texts written by Turkish authors in linguistics. The sample analyzed in the study, 20 scientific texts were chosen from the linguistic researches and linguistic
\end{abstract}

Bu makale Sevgi Çalışır’n “Türkçede bilimsel metinlerde olumsuzluk” adlı yüksek lisans tezinden üretilmiştir. Öğr. Gör. Dr., Anadolu Üniversitesi, Rektörlük Türk Dili Bölümü (Eskişehir, Türkiye), sevgicalisir@anadolu.edu.tr, ORCID ID: oooo-0002-7942-5452 [Makale kaylt tarihi: 21.05.2020-kabul tarihi: 20.09.2020; DOI: 10.2900o/rumelide.791135] 


\begin{abstract}
congress papers published in 1998-2006 by random sampling method. In the review, the numerical values were determined by performing a two-step count. In the first stage, the total number of words (2845) in the scientific texts written in Turkish was determined. Secondly, the number of negative sentences (210), which are included in the scientific texts written in Turkish in the field of linguistics, was determined. The negative sentences detected were arranged according to the text performance model of Swales (1990). The textual acts in which negative sentences used in Turkish scientific texts are most frequently used are; Generalizations on the Subject (80), Inference and Assumption (52), Research Lack Indication (22), Unexpected Result (22), Literature Review (14), Problem Indication (9), Description (4), Suggestion (2) , Limitations (2), Method (2), Data Collection (1). It was concluded that the negative sentences used in scientific texts affect the study credibility, reliability and adequacy etc.
\end{abstract}

Keywords: Turkish scientific texts, textual acts, negative sentences

\title{
Giriş
}

Dilbilimden psikolojiye kadar birçok alanda yaygın olarak incelenen, olumsuzluk dilbilimde evrensel bir dilbilgisel kategoridir. Bütün diller olumsuzluk kavramına sahiptir. Olumsuzluğun dilbilimselliği üzerine pek çok çalışma yapılmıştır. Bu çalışmaların çoğu biçimbilimsel, sözdizimsel ve anlambilimsel yapı üzerinedir. Bu alandaki çalışmaların da İngilizcede üzerine yapıldığı görülmektedir (Klima, 1964; Lasnik, 1969; Partee, 1970; Jackendoff, 1971; Taglicht, 1984; McGloin, 1986; Givon, 1984, 1990). Az sayıda dilbilimci, olumsuzluğun işlevsel ve edimsel çözümlemesini söylemsel veri üzerinde araştırmıştır (Labov, 1972a; Givon, 1978; Leech, 1983; Horn, 1985; Tottie, 1991; Pagano, 1994; Hwang, 1992; Cheshire, 1998 ve Jordan,1998). Fakat bu çalışmaların çoğunda metinsel düzlemde işaretlenen olumsuzluk göz ardı edilmiş, metinsel olumsuzluğa yeterince değinilmemiştir. Anlatı metinlerinde olumsuzluk konusu kısmen incelenmiş ancak bilimsel metinlerdeki olumsuzluk betimlenmemiştir. $\mathrm{Bu}$ nedenle söylem çalışmalarında bilimsel metin türünün olumsuzluk açısından incelenmesinde önemli bir boşluk doğmaktadır. Buradan hareketle, bu çalışma hem konuyla ilgili olarak ulaşılmış sonuçların Türkçe açısından sınanması ile kuramsal bir katkıyı hem de Türkçenin bu açıdan özel görünümlerini ortaya koyarak uygulamaya dönük bir katkıyı öngörmektedir.

Bununla birlikte Türkçede bilimsel metin üzerine yapılmış çalışmalar genellikle bilimsel çalışmanın yöntemi, araştırma teknikleri, niceliksel özellikleri üzerinde yoğunlaşılmaktadır. Bu çalışmalarda, bilimsel metnin bir tür olarak belirginleştirilmediği dikkat çekmektedir.

Bu çalışmanın amacı, dilbilim alanında Türkçe yazılmış bilimsel metinlerde kullanılan olumsuzluğun metinsel edimlere göre dağılımlarını incelemektir. Bu amaç doğrultusunda "Türkçe bilimsel metinlerde kullanılan olumsuzluk, metinsel işlev bakımından nasıl bir görünüm sergilemektir?” sorusu yanitlanacaktır.

Çalışmada, bilimsel metin türü içinde, Türk yazarlar tarafından yazılmış araştırma yazıları olumsuzluk sunumu açısından incelenerek bu konuda henüz çalışma yapılmamış olması nedeniyle doğan bu boşluk kapatılmaya çalışılacaktır. Bu çalışmanın sonuçlarından çıkarılması beklenebilecek uygulanabilir faydalar ise, varılan sonuçların, bilimsel metinler konusunda ileride yapılacak çalışmalara katkısının olmasidır. 
$\mathrm{Bu}$ çalışmada, dilbilim alanında Türk yazarlar tarafından yazılmış, Türkçe bilimsel metinlerin yüzey yapısında gözlemlenen eylem çekimli olumsuzluk işaretleyicisi olan -mE eki ile yapılan metinsel olumsuzluk ele alınacaktır.

\section{Bilimsel metin türü}

Bilimsel metin, belli bir söylem topluluğunu hedefleyen, doğrudan geçerli, güvenilir bilgi sunmayı amaçlayan; izlenebilir, gözlemlenebilir, dizgeli bir somutluktur.

Uzun (2001) metin cinsi (genre), metin türü (text type) ve metin alt türü (sub-type) ayrımı yapmıştır. $\mathrm{Bu}$ ayrıma göre, metinler amaçları doğrultusundaki işlevlerine göre, genelden özele doğru sırasıyla: 'Bilgilendirici metin cinsi' (expository text), bilgilendirici nitelikli tüm metin türlerini (haber metinleri, ders kitapları, bilimsel metinler vb.) kapsamaktadır. Bilgilendirici nitelikli olan 'bilimsel metin türü' ise, bu türün beklentileri doğrultusunda yazılmış tüm 'alt türleri' (araştırma yazıları, laboratuvar raporları, tanıtma yazıları vb.) kapsamaktadır. Örneğin bir araştırma yazısı, bilgilendirici metin cinsi kapsamındaki bilimsel metnin bir alt türüdür.

Metin üretim aşamaları metnin türüne özgü yapılanmalarla sıkı bir ilişki içindedir. Metin üretme aşamaları hemen her metin türü için geçerliyken, türe özgü yapılanmalar doğrudan söylem bağlamını belirlemektedir. Bu nedenle türe özgü yapılanmalar, üretim sürecinden ayrı düşünülemez niteliktedir. Metin üretim aşamaları ve türe özgü yapılanmalar arasındaki ilişki üretilecek metnin amacına hizmet etmektedir (Huber ve Uzun 1999: 4).

Türler, metinlerin üretim amaçlarına göre, biçimlerine göre, üretici tarafından hedeflenen söylem topluluğunun beklentileriyle şekillenen, belli geleneklere dayalı kurallar çerçevesinde ortaya konmuş metinlerle somutlaşmaktadır.

Bilimsel metin türünde metin, düzenli bir süredizimsel çizgisellik gösterirken, yazınsal türlerde bu çizgisellik, yazarın kendi tercihleri doğrultusunda kırılmalar gösterebilmektedir.

Bilimsel metinlerin ilk ve temel özelliği metin olmalarıdır. Metnin belli bir tür içinde gerçekleştirilmesi, onun belli bir söylem topluluğunun beklentilerine uygun biçimde düzenlenmesiyle mümkün olmaktadır.

Bu çerçeveden bakıldığında, belli bir söylem topluluğunu hedefleyen; doğrudan geçerli, güvenilir bilgi sunmayı amaçlayan; izlenebilir, gözlemlenebilir, dizgeli bir somutluk olan bilimsel metin (scientific text), ayrı bir tür olarak belirginleşmektedir. Bu tür içinde, metinleştirme (textualization) yöntemi doğrultusunda farklı dillerde ve çalışma alanlarında gerçekleştirilmiş olan 'bilimsel metin' bir tür evrensel iletişim biçimi olan bilimsel söylemi (scientific discourse) oluşturmaktadır. (Widdowson, 1979: 52)

Her bilimsel araştırmanın gücül hedefi vargılar ortaya koymaktadır. Vargılar, araştırmacıların bulguları üzerine geliştirdikleri soyut ilişkileri içermektedir. Bilimsel metin okuyucusunun temel amacı, bilgilenmektir. $\mathrm{Bu}$ amaç doğrultusunda okuyucu metinde bilgi dünyasının nesnel gerçekliğinin yansıtılmasını bekler. Bu nedenle, bilimsel metinlerde, okuyucunun ilgili araştırmayı konusu, amacı, sinılılıkları, kuramsal çerçevesi, kullanılan terimlerden araştırmacının neyi anladığı, verinin çözümlenişinde kullanılan terimlerden araştırmacının neyi anladı̆̆ı, verinin çözümlenişinde kullanılan tekniklerin ne olduğu, gerekçeleri eşliğinde bulguları ve vargılarıyla bir bütün olarak kavraması 
hedeflenmektedir.

Bilimsel metinlerde nesnellik, bilginin nesnelliğinden öte, metin dünyasına özgü nesnel sunumu işaret etmektedir. Bilimsel metinlerde nesnellik, kendini metin dünyasında sözbilimsel olarak gösterir.

Bilimsel metinlere özgü metin dünyasına yönelik olarak belirginleştirilmiş beklentiler ile bu beklentilerle ilişkilendirilmiş dilsel ve sözbilimsel önbiçimlenişler, bilimsel bir metni işlevsel ve etkileşimsel olarak diğer metin türlerinden ayırmaktadır. Türünü belirginleştirmiş bir bilimsel metin, katkısını yani sunduğu yeni bilgileri odaklayabilmekte, yazarın metindeki yeni bilgileri ve onları güdüleyen diğer bilgileri dizgeli ve dengeli bir biçimde ortaya koyabilmesini sağlamaktadır. Böylece, bilimin nesnellik ilkesi çerçevesinde kalarak bu metin türüne özgü iletişimsel işlevini, yani bilgi sunmayı amaçlayan betimselliğini yerine getirmektedir (Uzun, 2001: 201-203).

Swales (1990)'in daha çok deneysel araştırma makalelerine dayanarak geliştirdiği modele göre, bir araştırma makalesinin ana iletişim amacı makalede betimlenen araştırmanın bilime gerçek bir katkı sağladığına okuyucuları ikna etmektir. Bu nedenle de Swales (1990: 141-142), araştırma makalesi yazma eylemine bilim alanında bir 'araştırma yeri yaratma' eylemi olarak bakılabileceğini söyler. Swales (1990), makale yapılarını bir dizi iletişim edimleri olarak incelemektedir. İnceleme birimi olarak önerdiği metinsel edimlerinin dilsel ifadesi tümce ile paragraf arası büyüklükte anlamsal bir birim olup yazarın belli bir amacına karşılık gelir. Şekil 1.'de metinsel edimler makalelerin yapısına göre ayrılmıştır (Swales, 1990; akt. Ruhi, 2002: 162-164). 


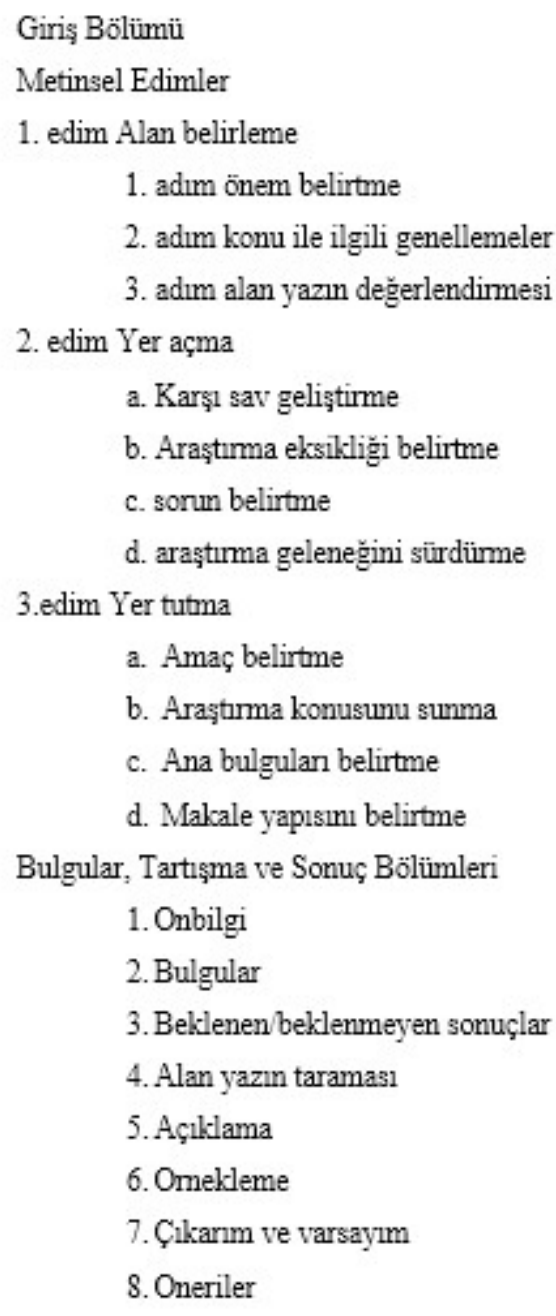

Şekil 1. Makalelerin Retorik Yapısı

\section{Olumsuzluk kavramı ve türleri}

Olumsuzluk, olumlu önermenin veya onun bazı parçalarının inkârına gönderimde bulunur. Ackrill (1963; akt. Horn, 1985) olumsuzluğun, olumlu tümceyi önvarsaydığını belirtmektedir. Bosonquet (1888: 294), olumlu olan her şeyin inkâr edilebileceğini belirtir. Kraak (1966: 89) her olumlu tümceye eşlik eden bir olumsuz tümcenin var olduğunu veya bunun tam aksinin de olabileceğini söylemiştir.

Olumsuzluk, önermenin tamamın kapsıyorsa, sözdizimsel olarak tümcesel olumsuzluk (sentential negation) olarak biçimlenir ve tümcenin mantıksal yapısında geniş açıya sahip olduğu söylenir. Tümcesel olumsuzluk aynı zamanda anlamsal yapıda önermesel olumsuzluk (propositional negation) olarak da adlandırılır. Anlambilimde çalışılan olumsuzluk çeşidi, önermesel olumsuzluktur (Payne, 1985 tümcesel olumsuzluk olarak adlandırmaktadır). Tümcesel olumsuzlukta görülen olumsuzluk elemanları anlamsal yapıda dısssal (external) olumsuzluk yöneticileri olarak bilinmektedir. Bunlar eylemcil yüklemlerde dar açı (narrow scope) alarak içsel (internal) olumsuzluk yöneticileri olurlar.

Çok yaygın olarak kullanılan diğer bir terim ise, standart olumsuzluktur. Eylemcil olumsuzluk da denilmektedir. Payne (1985) standart olumsuzluğu, tümcesel olumsuzluktan ayırır. Standart 
olumsuzluk, dilde tümceyi olumsuzlama yollarından en tipik olanıdır. Bu tip olumsuzluk temel tümcelerde görülür. Standart olumsuzluk Türkçede, eylem tümcelerinde $-\mathrm{mE}$ ile, eylem olmayan tümcelerde "değil” ile işaretlenmektedir. Dildeki standart olumsuzluk işaretleyicisi her zaman tümcesel olumsuzluk yaratmayabilir, çünkü açıуı değiştiren elemanlar tarafından, sözgelimi niceleyiciler, etkilenir.

Horn (1985)’a göre, olumsuzluk iki biçimde görülür: betimleyici (descriptive) ve edimsel olumsuzluk (metalinguistic negation) terimlerini kullanır. Horn'un edimsel olumsuzluk terimi yerine McCawley (1993:189) karşıtlı bildiren olumsuzluk (contrastive negation) (X değil fakat Y) terimini kullanmaktadır. Betimleyici, yukarıda bahsedilen standart olumsuzluğa gönderimde bulunur. Olumlu önermenin, mantıksal inkârıdır. Bu yüzden, koşullu gerçeklik gösterir. Edimsel olumsuzluk, edimsel bir kavramdır ve önermenin doğruluk değeriyle ilgili değildir. Yalnızca bağlamdaki görünümleri reddeder. $\mathrm{Bu}$ yüzden önermenin inkârı ile sonuçlanmaz, koşullu gerçeklik taşımaz. Edimsel olumsuzluk, betimleyici olumsuzluktan daha özneldir; çünkü konuşucunun yargısının altında kabul etmeme yatar. Aynı zamanda, Traugott'un (1989) iddia ettiği gibi edimsel olumsuzluğun metinsel ve anlatımsal bir işlevi vardır. Horn (1985) bu tip olumsuzluğun sadece anlatım biçimini reddettiğini değil, aynı zamanda bağlamdaki herhangi bir niteliği de reddettiğini vurgular.

Onizan (2005)'a göre söylemsel olumsuzluk (discourse negation), daha önceden bahsedilen bir olayın düzeltilmesi için kullanılır. Düzeltme (correction), aynı konuşucu tarafından üretilen ifadenin inkârıdır. Konuşucu söylediklerinin doğru olmadığını ya da doğru olduğunu fark eder, bu yüzden söylediklerini değiştirir. Anlatılarda anlatıcı tarafından veya diyaloglarda konuşucu tarafından eklenebilir.

Metinde olumsuzluk, varsayımın (assumption) inkârı veya beklentinin olumsuzlanması gibi işlevlere sahiptir (Wason, 1965; Hwang, 1992; Pagano, 1994; Jordan, 1998; Werth, 1999). Hidalgo Downing (2000a), olumsuzluğu aynı şekilde değerlendirir. Olumsuzluğun doğasının beklentilerin veya varsayımların inkârı olduğunu belirtmektedir. Araştırmacı olumsuz tümcelerin, kabul edilebilir bilgileri, yani doğru veya gerçek olduğuna inanılan bilgileri, inkâr edebildiğini belirtmektedir. Beklentiler, farklı çeşitlerde temellendirilebilmektedir. Werth (1999)'e göre, olumsuzluk her zaman beklenen, normal ya da sıradan olan bir durumun tam zittını yönetmektedir. Bazı beklentiler kültüreldir. Diğer tip beklentiler, bireysel deneyimlerle şekillenmektedir. Bunun bir kısmı genel bilgiye dayalı beklentidir. Metni anlamak için sözcüklerin ya da tümcelerin anlamlarını bilmek yetmez, aynı zamanda temel bir bilgiye ihtiyaç vardır. Çalışır (2007) bilimsel metinlerdeki olumsuzluğun sunumunu diğer çalışmalardan farklı olarak araştırmacının öngördüğü beklentiler adı altında toplamıştır. Okura yönelik öngörüler ve araştırmacının bireysel beklentisine yönelik öngörüler olmak üzere ikiye ayırmıştır.

\section{Yöntem}

$\mathrm{Bu}$ çalışmada, doküman inceleme yöntemi kullanılmıştır. Doküman incelemesi, araştırılması hedeflenen, olgu ya da olaylar hakkında, bilgi içeren yazılı materyallerin analizini kapsar (Şimşek, 2009).

\section{Verilerin toplanması}

Çalışmanın veri tabanı, dilbilim alanında Türk yazarlar tarafından yazılmış Türkçe bilimsel metinlerden oluşmaktadır. Çalışmada incelenen örneklem, 1998-2006 yıllarında yayımlanan Dilbilim Araştırmaları ve Dilbilim Kurultay Bildirileri’nden rastlantısal örnekleme yöntemiyle 20 bilimsel metin seçilmiştir. Bu 
kitaplarda araştırma yazıları dışındaki yazılar (tanıtma yazıları, çeviriler vb.) örneklemin seçildiği kitlenin dışında bırakılmıştır.

\section{Verilerin çözümlenmesi}

İncelemede kullanılacak bilimsel metinler (toplam 20 metin) bilgisayar ortamına aktarılmıştır, sayısal değerler iki aşamalı bir sayım yapılarak saptanmıştır. Sayımın birinci aşamasında dilbilim alanında Türkçe yazılmış bilimsel metinlerdeki toplam sözce sayısı (2845) saptanmıştır. Bunun ardından ikinci olarak dilbilim alanında Türkçe yazılmış bilimsel metinlerde yer almakta olan olumsuz sözcelerin (210) sayısı saptanmıştır. Saptanan olumsuz sözceler Swales (1990)'in metinsel edim modeline göre düzenlenmiştir. Düzenlenen veriler uzman görüşü alınarak kontrol edilmiş, elde edilen bulgular sayısal olarak tablolaştırılmıştır.

\section{Bulgular}

Bu bölümde dilbilim alanında Türkçe yazılmış bilimsel metinlerde metinsel edimlerin doğrultusunda olumsuz tümcelerin dağılımlarına ilişkin bulgular sunulacaktır.

Tablo 1'de çalışmanın veri tabanında yer alan bilimsel metinlerdeki olumsuz tümcelerin metinsel edimlere göre dağılımları görülmektedir.

Tablo 1. Metinsel edimlere göre olumsuz tümcelerin sayısı

\begin{tabular}{ll}
\hline Metinsel Edimler & Olumsuz Tümce Sayısı \\
\hline Konu ile İlgili Genellemeler & 80 \\
\hline Çıkarım ve Varsayım & 22 \\
\hline Araştırma Eksikliği Belirtme & 22 \\
\hline Beklenmeyen Sonuç & 14 \\
\hline Alan Yazın Değerlendirmesi & 9 \\
\hline Sorun Belirtme & 4 \\
\hline Açıklama & 2 \\
\hline Öneri & 2 \\
\hline Sinırlılıklar & 2 \\
\hline Yöntem & 1 \\
\hline Veri Toplama İşlemleri & 210 \\
\hline Toplam Olumsuz Tümce Sayısı & 22 \\
\hline
\end{tabular}

Tablo 1'de sinırlılık, yöntem ve veri toplama işlemleri edimleri gibi Swales (1990)'in modelinde söz edilmeyen edimler de yer almaktadır. Verilerden edinilen bulgulara dayanarak bu edimler Tablo 1'e eklenmiştir. Tablo 1'e göre, Türkçe bilimsel metinlerde kullanılan olumsuz tümcelerin, en sık kullanıldığı metinsel edimler sırasıyla; Konu ile İlgili Genellemeler (80), Çıkarım ve Varsayım (52), Araştırma Eksikliği Belirtme (22), Beklenmeyen Sonuç (22), Alan Yazın Değerlendirmesi (14), Sorun Belirtme (9), Açıllama (4), Öneri (2), Sinırlılıklar (2), Yöntem (2), Veri Toplama İşlemleri (1)'dir. 
Olumsuz tümcelerin en fazla görüldüğ̈̈ metinsel edimlerin ilki konu ile ilgili genellemelerdir.

80 olumsuz tümce konu ile ilgili genelleme edimini işaret etmektedir. Bu edimle ilgili olumsuz tümce örnekleri şunlardır:

(1) Bu kez İngilizcede erkek ve dişi olmak üzere ayrı ayrı cinsiyetleri ifade edilerek kullamlan 3. tekil kişi adıl Türkçede bir tek "o" ile ifade edilmekte ve cinsiyet ayrmmı işaret etmemektedir. (Metin 1)

(2) Yani, ses tellerindeki titreşimin gecikmesi örneğin 5 milisaniye ve 15 milisaniye olduğunda iki sesin ikisi de /b/ olarak duyulur ve ayzrt edilemez. (Metin 2)

(3) Dil kullanıldığı toplumdan soyutlanamaz. (Metin 3)

Olumsuz tümcelerin en sık kullanıldığı ikinci edim, çıkarım ve varsayım edimidir. Aşağıda bu edime ilişkin olumsuz tümce örnekleri sunulmuştur:

(4) Bu demektir ki kaynak dilde kullanılan bir kişi adılın aynı söz dizimsel ve anlamsal özellikleriyle birlikte erek dilde bulmak olasılığı her zaman olmayabilir. (Metin 1)

(5) Bu örtük değiştirimler dikkat çekici olmadığından sunucu eğer çok önemli değilse katılımcinın yanıtının kaçamak olduğunu anlamayabilir. (Metin 4)

Olumsuz tümcelerin görüldüğü diğer edim, araştırma eksikliği belirtmedir.

(6) Söylem belirleyicileri daha önce pek çok dilbilimci tarafindan incelenmiş, ancak Frase’in (1999:931) belirttiği gibi, nasıl tanımlanmaları gerektiğine veya ne tür işlevlere sahip olduklarına dair kesin bir uzlaşmaya varılamamaştur. (Metin 5)

(7) Haliday ve Hasan (1976) İngilizcede bağdaşıklık üzerine çalışırken söylem belirleyicilerinden direk olarak bahsetmemişlerdir ancak daha sonra bu terimle anlacak olan ve, ama, çünkü, yani gibi sözcüksel ifadelere değinmişlerdir. (Metin 5)

(8) Ancak alanyazında ayrı tümcenin başl başına bir araştırma konusu olarak ele alındiğı bir çalışmaya rastlanmameşter. (Metin 6)

Olumsuz tümcelerin görüldüğü dördüncü edim beklenmeyen sonuçtur. Örneklerden bazıları şunlardır:

(9) Bu şüpheli önceden taksi şoförlüğü yapmış olmasına ve cinayet işlendiği yere defalarca servis yapmasına rağmen, olay yerinin geçtiği sözcelerle ilgili hiçbir şey söylememiştir. (Metin 7)

(10) Sözlü dil özellikleri taşıyan üçüncü metin haricinde diğer iki metinde herhangi bir hitap sözcüğüne rastlanmamaktador. (Metin 8)

(11) Ancak bu çalışmada /a/ ünlüsü bulunduğu her iki hece yapısında da vurgu almamaktadrr. (Metin 9)

Alan yazın değerlendirmesi ediminde görülen olumsuz tümce sayısı 14'tür. Tümleyici gönderim ve tümleyici olmayan gönderim şeklinde iki alt bölümden oluşmaktadır. 
a) Tümleyici gönderim

(12) Türkçenin dilbilgisi çalışmalarında diye yapısının neden gösteren bir ilgeç yapısı olduğu Underhill (1976)'dan önce gözlemlenmemiştir. (Metin 10)

b) Tümleyici olmayan gönderim

(13) "Evet/Hayır" sorularınn yanıtları belirgin olsa da "Neden/Niçin" sorularnnn yamıtları büyük çapta açılama, betimleme, örnekleme ve ayrıntı gerektirebileceğinden bu tür soruların yantlarının sinıflandirlması kolaylikla kesinlik kazanamamaktadrr (Haris, 1991). (Metin 11)

(14) Boş, düz, kuru, dolu, sert gibi sıfatlarda derece, herhangi bir standardı aşmak veya altında kalmak anlaminda yorumlanmaz (Kennedy\&McNally, 1999). (Metin 12)

Sorun belirtme ediminde gözlemlenen olumsuz tümce sayısı 9'dur. Aşağıda örnekleri sunulmuştur:

(15) Yükseköğretim kurumlarnnda daha bilinçli bir politikanın izlendiği söylenemez. (Metin 3)

(16) Bu görüşten yola çıkarak eğitimde de yazılı dil becerisinin kazandırılması ön plana alınmakta ve sözlü dil becerilerinin kazandırlmasına yönelik etkinliklere pek yer_verilmemektedir. (Metin 3)

Olumsuz tümcelerin gözlemlendiği diğer bir edim açıklamadır. Bu edime ilişkin örnekler şunlardır:

(17) Çünkü kullanılan yapıyla önerilen eylemi alıcmın kabul veya reddetmesine olanak tanıyan bir durum yarathlmamaktador. (Metin 13)

(18) Edimsel ilişki de tek yönlü kurulmaz. Çünkü ekler tek bir ilişki yönü belirlemez İngilizceden yola çıklırsa, İngilizcede bulunmayan gölgeli olan alan içindeki Türkçe özellikler ya çarpık olarak belirlenmiş ya da yalnızca İngilizceye çevrilmiş olur. (Metin 14)

Olumsuz tümcelerin görüldüğü bir sonraki edim öneridir. Örneklemde öneri edimini gösteren 2 olumsuz tümce saptanmıştır.

(19) Metin üreticisinin amaçlarım ve iletişimdeki rolünü, metin alıcısının beklentilerini, metinde geçen bağlamları belirlemeden incelemeye girişilmemelidir. (Metin 7)

Olumsuz tümcelerin görüldüğü diğer edim sınırlılıktır. Toplam 2 olumsuz tümcede görülmüştür. Bir örnek sunulmuştur:

(20) Söylemde söz konusu göndergelere ilişkin bilginin sürekliliğini sağlayan artgönderimsel biçimlerin 3. kişi göndergelerinin incelemesiyle belirlenebileceği varsayıldiğı için 1. ve 2. kişi göndergeleri çalışma kapsamma almmamıştır. (Metin 15)

Yöntem ediminde 2 olumsuz tümce saptanmıştır.

(21) 4 denek de Anadolu Üniversitesi Ĕ̆itim Fakültesi öğrencisi olup çalışmanın yapıldığı zamanda dilbilim ve sesbilime yönelik dersler almamışlardor. (Metin 16)

Veri toplama işlemleri edimi, 1 olumsuz tümcede gözlemlenmiştir. 
(22) Konuşmayı doğal akıcılı̆̆ içinde kayıt edebilmek için kayıt sürecinde konuşmacıların kayıt edildiklerinden haberleri olmamıştur. (Metin 17)

\section{Sonuç ve tartışma}

$\mathrm{Bu}$ çalışmada dilbilim alanında Türkçe yazılmış bilimsel metinlerde kullanılan olumsuzluğun metinsel edimlere göre dağılımları incelenmiştir. Bu amaç doğrultusunda "Türkçe bilimsel metinlerde kullanılan olumsuzluk, metinsel işlev bakımından nasıl bir görünüm sergilemektir?” sorusuna yönelik olarak şu sonuçlara ulaşılmıştır:

Çalışmada, Swales (1990)'in bilimsel makaleler için öngördüğü metinsel edimler ve buna ek olarak bazı adımların (sınırlılık, yöntem ve veri toplama işlemleri edimleri) bulunduğu gözlemlenmiştir.

Olumsuz tümcelerin en fazla görüldüğü metinsel edimlerin ilki konu ile ilgili genellemelerdir. Alan belirtmenin ikinci adımı olan konu ile ilgili genellemeler, kuramsal ya da deneysel yolla edinilmiş bilgi ve gerçekler hakkında yapılan genellemelerdir ve alan belirtme adımına göre daha az iddialı bir dille ifade edilmesi beklenir (Swales 1991: 146). Konu ile İlgili Genellemelerde kullanılan olumsuz tümceler, kuramsal ya da deneysel yolla edinilmiş bilgi ve gerçekler hakkında yapılan genellemelerin inandırıcılığını azaltmaktadır.

Olumsuz tümcelerin en sık kullanıldı̆̆ı ikinci edim, çıkarım ve varsayım edimidir. Çıkarım ve varsayım ediminde görülen olumsuz tümcelerin kullanım sıklık oranı ve eylemelere eklenen geçicilik bildiren EbIl biçimbiriminin kullanımı, araştırmacının kesin bilgilerle yaklaşmadığını göstermektedir. Çıkarım ve varsayımda kullanılan olumsuz tümceler, araştırmacının kesin sonuçlara ulaşamadığını göstermekte ve çalışmanın güvenilirliğini düşürmektedir.

Olumsuz tümcelerin görüldüğü diğer edim, araştırma eksikliği belirtmedir. Bu adım daha önceki çalışmaların eksikliklerinin belirtmektedir. Zeyrek (2002)'e göre bu adım ancak, buna rağmen, fakat gibi zıtllk gösteren bağlaçlar; hiç, az gibi olumsuzluk gösteren belirteçler ve eylemlere eklenen olumsuzluk biçimbirimleriyle anlaşılmaktadır. Zeyrek (2002), bu adımın üst söylem belirleyicileri derleminde \%2 gibi oldukça düşük ağırlıkta görülmesine karşın, dilbilgisel açıdan dağınık yapılara sahip olmadığını belirtmektedir. Toplam 22 olumsuz tümce bu edimde görülmektedir. Araştırma Eksikliği Belirtme ediminde kullanılan olumsuz tümceler, araştırmacının önceki çalışmaları yetersiz bulduğunu, kendisine yer açmak istediğini göstermektedir.

Olumsuz tümcelerin görüldüğü dördüncü edim beklenmeyen sonuçtur. Bu bölüm araştırmacının sonuçları değerlendirirken başvurduğu bir edimdir. Beklenmeyen Sonuç ediminde görülen olumsuz tümceler, araştırmacının vargılarına ulaşamadığını, çalışmanın amacının istediği doğrultuda gerçekleşemediğini göstermektedir.

Alanyazını değerlendirmesi ediminde görülen olumsuz tümce sayısı 14’tür. Bu edimde saptanan olumsuz tümcelerin kullanımı, tartışılan konuyla ilgili önemli çalışmalara yapılan gönderimin dilsel göstergesidir, önceki çalışmaların eksik olduğunu göstermektedir.

Sorun belirtme ediminde gözlemlenen olumsuz tümce sayısı 9'dur. Bu edimde gözlemlenen olumsuz tümceler, araştırmacının, diğer çalışmaların birtakım sorunlar içerdiğini, buradan hareketle okuyucuyu yönlendirmeye çalıştığını aynı zamanda çalışmasını gerekçelendirdiğini göstermektedir. 
Olumsuz tümcelerin gözlemlendiği diğer bir edim açıklamadır. Açıklama ediminde kullanılan olumsuz tümceler, araştırmacının alanyazınındaki sonuçların zıttı bir sonuçla karşılaştığını göstermektedir.

Olumsuz tümcelerin görüldüğü bir sonraki edim öneridir. Örneklemde öneri edimini gösteren 2 olumsuz tümce saptanmıştır. Öneride kullanılan olumsuz tümceler ise, yazarın metindeki varlığını ve karşısındaki okuyucuyu uyarma amacı içinde olduğunu; yani yazar-okur arasındaki etkileşimin öne çıarıldığını göstermektedir. Olumsuzluk işaretleyici -mA'nın -mAlı kip ekiyle birlikte kullanıldığı görülmüştür.

Olumsuz tümcelerin görüldüğü diğer edim sinırlllıtır. Toplam 2 olumsuz tümcede görülmüştür. Sınırlılık ediminde incelenen olumsuz tümceler, çalışmada hangi konuları incelemediğini, metin dışı bıraktığını göstermektedir.

Yöntem ediminde 2 olumsuz tümce saptanmıştır. Olumsuz tümcelerin kullanımı, araştırmacının okuyucuya araştırmanın yöntemiyle ilgili bilgi verdiğini, okuyucuyu çalışmanın nesnelliği konusunda ikna etmeye çalıştığını göstermektedir.

Veri toplama işlemleri edimi, 1 olumsuz tümcede gözlemlenmiştir. Araştırmacının araştırma tekniğini anlattığı edimdir. Bu edimde gözlemlenen olumsuz tümce, çalışmanın geçerliliğini göstermektedir.

\section{Kaynakça}

Bosanquet, B., (1888). Logic, Vol. 1, Oxford: Clarendon.

Cheshire, J. (1998). English negation from an interactional perspective in the sociolinguistics reader. Multilingualism and Variation, 127-44.

Çalışır, S. (2007). Türkçede bilimsel metinlerde olumsuzluk. Yayımlanmamış yüksek lisans tezi. Anadolu Üniversitesi.

Givon, T. (1978). Negation in language: pragmatics, function, ontology. Syntax and Semantics 9, 69112.

Givon,T. (1984). Syntax: a functional typological introduction. Amsterdam: Benjamins.

Givon, T. (1990). Syntax: a functional typological introduction. Amsterdam/Philadelphia: John Benjamin, Vol. II.

Hidalgo, Downing L. (2000a). Negation in discourse: a text world approach to Joseph Heller's catch-22, Language and Literature 9, 3, 215-39.

Horn, Laurence R. (1985). Metalinguistic negation and pragmatic ambiguity. Language 61, 121-174.

Huber, E. ve Uzun, L. (1999). Bilimsel çalışma kılavuzu. Essen Üniversitesi Yayınları.

Hwang, S. J. J. (1992). Language in context. Hwang, Shin Ja J. ve Merrifield, W. (Eds.), The functions of negation in narration. Dallas: The Summer Institute of Linguistics and The University of Texas at Arlington.

Jackendoff, R. (1971). On some questionable arguments about quantifiers and negation. Language 47, 284-297.

Jordan, M. P. (1998). The power of negation in English: text, context and relevance. Journal of Pragmatics 29, 1, 705-52.

Kraak, A. (1966). Negatieve zinnen. Hilversum: De Haan.

Klima, E. S. (1964). Negation in English. The Structures of Language, 246-323.

Labov, W. (1972a). The transformation of experience in narrative syntax. Philedelphia: University of Pennysylvania State. 
Lasnik, H. (1969). Analysis of negation in English. Yayınlanmamış doktora tezi. Harvard Üniversitesi. Leech, G. (1983). The principles of pragmatics. London: Longman.

McGloin, N. H. (1986). Negation in Japanese. Boreal Schotarly Publishers and Distributors Ltd.

Onizan, N. (2005). Functions of negation in Arabic literary discourse. Yayınlanmamış doktora tezi. Kansas Üniversitesi.

Pagano, A. S. (1994). Negatives in written text. Advances in written text analysis, 250-65.

Partee, B. H. (1970). Negation, conjuction and quantifiers: syntax vs. semantics. Foundations of Language 6, 153-165.

Payne, J. (1985). Negation. Language typology and syntactic description. Cambridge: Cambridge University Pres.

Ruhi, Ş. (2002). Türkçede bilgi yapısı ve bilimsel metinler. L. Uzun ve E. Huber (Ed.), Türkçe psikoloji makalelerinde tartışma yapısı. Essen: Die Blaue Eule.

Swales, J. M. (1990). Genre analysis English in academic and research settings. Cambridge: Cambridge University Press.

Şimșek, H. (2009). Eğitim tarihi araștırmalarında yöntem sorunu. Ankara Üniversitesi Eğitim Bilimleri Fakültesi Dergisi, 42(1), 33-51.

Taglicht, J. (1984). Message and emphasis: on focus and scope in English. London: Longman.

Tottie, G. (1991). Negation in English speech and writing: a study in variation. San Diego, CA: Academic.

Traugott, E. (1989). On the rise of epistemic meanings in English: an example of subjectivization in semantic change. Language 65, 31-55.

Uzun, L. (2001). Bilimsel metne özgü önbiçimlenişler ve bilimsel metin yazma edimi. Anatolia: Turizm Araştırmaları Dergisi 12, 197-204.

Wason, P. C. (1965). The context of plausible denial. Journal of Verbal Learning and Verbal Behaviour 4, 7-11.

Werth, P. (1999). Text worlds: representing contextual space in discourse. London: Longman.

Widdowson, H. G. (1979). Explorations in applied linguistics. Oxford: Oxford University Press.

Zeyrek, D. (2002). Türkçede bilgi yapısı ve bilimsel metinler. L. Uzun ve E. Huber (Ed.), Psikoloji makalelerinde üstsöylem belirleyicileri. Essen: Die Blaue Eule. 